\title{
Avoid adding insult to injury - correct management of sick female endurance athletes
}

\author{
T Hew-Butler, J Boulter, R Bhorat, T D Noakes \\ School of Health Science, Oakland University, Rochester, MI, USA \\ T Hew-Butler, DPM, PhD \\ Chief Medical Officer, Comrades Marathon, Scottsville, Pietermaritzburg \\ J Boulter, MB ChB
}

Vincent Pallotti Hospital, Cape Town

R Bhorat, MB ChB

MRC/UCT Research Unit for Exercise Science and Sports Medicine and Department of Biology, University of Cape Town T D Noakes, MB ChB, MD, DSc

Corresponding author: T Hew-Butler (hew@oakland.edu)

\begin{abstract}
Objectives. To evaluate the efficacy of Ringer's lactate, isotonic saline and hypertonic saline on the clinical and biochemical recovery of athletes with exercise-associated hyponatraemic encephalopathy caused by fluid overload.

Methods. We retrospectively reviewed serial blood sodium concentrations $\left(\mathrm{Na}^{+}\right)$and qualitative signs of recovery and time to recovery in two healthy menstruant females hospitalised with dilutional exercise-associated hyponatraemic encephalopathy after withdrawal from the 2011 Comrades Marathon $(89 \mathrm{~km})$ and Argus Cycle Tour (109 km).

Results. Improvements in blood $\mathrm{Na}^{+}$did not occur with intravenous administration of Ringer's lactate solution, but did occur with administration of isotonic and hypertonic saline. Qualitative improvements in mental status were not quantitatively related to the biochemical value of blood $\mathrm{Na}^{+}$or subsequent return to normonatraemia.

Conclusions. Hyponatraemia should be suspected in all female athletes presenting to the medical area of endurance races with vomiting, altered mental status and a history of high fluid intake. If a diagnosis of exercise-associated hyponatraemia with cerebral encephalopathy is confirmed, the treatment of choice is administration of an intravenous bolus of hypertonic saline. Administration of Ringer's lactate should be discouraged, as this does not correct $\mathrm{Na}^{+}$and appears to delay recovery.
\end{abstract}

S Afr Med J 2012;102(12):927-930. DOI:10.7196/SAMJ.6156

Exercise-associated hyponatraemia (EAH) in South African endurance athletes had become rare since it was first described in three Comrades Marathon runners in $1985 .{ }^{1}$ Since that report, educational steps highlighting the potential hazards of overdrinking during endurance exercise minimised the incidence and morbidity of EAH in South African endurance races. ${ }^{2-4}$ However, recently two severe cases of EAH have come to our attention (case 1 from the Comrades Marathon and case 2 from the Argus Cycle Tour) that highlight the need to disseminate the latest evidence-based information, particularly with regard to optimal treatment strategies for EAH.

\section{Case reports}

\section{Case 1}

A healthy 28-year-old woman with an unremarkable past medical history and on no medications, running her second $89 \mathrm{~km}$ Comrades Marathon, pulled out at $76 \mathrm{~km}$ in $\sim 10.5$ hours feeling dizzy and weaving across the road. During the race she had followed her normal practice of ingesting a GU packet with $200 \mathrm{ml}$ of water every 45 minutes along with Coke and water ad libitum for an estimated fluid consumption rate of $\sim 550 \mathrm{ml} / \mathrm{h}$. She said that she had passed urine four times during the race of 'good volume', the last time just under half way $(40 \mathrm{~km})$. She had trained exactly the same as the year before (when she had completed the race in a time of 11 hours and 48 minutes), was not injured, and did not take any medications immediately before or during the race. Two weeks before the race, however, she was diagnosed with sinusitis and dispensed ciprofloxacin, the last dose of which was taken two days before the start of the race. She felt well enough to run on race day.

She remembers lying down at the aid station before becoming confused; she then vomited and suffered a grand mal seizure. She was transported via ambulance to the local hospital where a diagnosis of hyponatraemia was confirmed, with a serum sodium concentration of $112 \mathrm{mmol} / \mathrm{l}$ associated with pulmonary oedema (bilateral lung crackles) and encephalopathy (Glasgow Coma Scale (GCS) score of 9/15). She was quickly intubated, given a $40 \mathrm{mg}$ bolus of furosemide plus $5 \mathrm{mg}$ diazepam intravenously, and transported to the local intensive care unit (ICU).

In hospital she had three more seizures and was given Ringer's lactate $(250 \mathrm{ml} / \mathrm{h})$, potassium chloride (KCl: 2 ampoules in $200 \mathrm{ml}$ $0.9 \%$ saline) and sodium bicarbonate ( $8.5 \%$ for metabolic acidosis). A chest X-ray showed an infiltrate in the right upper lobe. Initial biochemical analyses revealed the following blood concentrations (reference ranges in brackets): sodium $\left(\mathrm{Na}^{+}\right) 114 \mathrm{mmol} / \mathrm{l}(136-145$ $\mathrm{mmol} / \mathrm{l})$; potassium $\left(\mathrm{K}^{+}\right) 3.4 \mathrm{mmol} / \mathrm{l}(3.5-5.1 \mathrm{mmol} / \mathrm{l})$; chloride (Cl) $78 \mathrm{mmol} / \mathrm{l}(98-107 \mathrm{mmol} / \mathrm{l})$; bicarbonate $(\mathrm{BIC}) 11 \mathrm{mmol} / \mathrm{l}$ (22 - $29 \mathrm{mmol} / \mathrm{l})$; urea $3.4 \mathrm{mmol} / \mathrm{l}(1.7-8.3 \mathrm{mmol} / \mathrm{l})$; creatinine (creat) $93 \mu \mathrm{mol} / 1$ (49 - $90 \mu \mathrm{mol} / \mathrm{l})$, creatine phosphokinase (CK) 
$2699 \mathrm{U} / \mathrm{l}(26$ - $192 \mathrm{U} / \mathrm{l})$; and white blood cell count (WBC) $23.7 \times 10^{9} / 1$ (3.9 $\left.-9.8 \times 10^{9} / 1\right)$. Nine hours later, the values were as follows: $\mathrm{Na}^{+}$ $116 \mathrm{mmol} / \mathrm{l} ; \mathrm{K}^{+} 3.8 \mathrm{mmol} / \mathrm{l}$; Cl- $85 \mathrm{mmol} / \mathrm{l}$; BIC $19 \mathrm{mmol} / \mathrm{l}$; urea 2.7 $\mathrm{mmol} / \mathrm{l}$; and creat $65 \mu \mathrm{mol} / \mathrm{l}$. The patient was then switched to $0.9 \%$ saline rehydration $(200 \mathrm{ml} / \mathrm{h})$ on day 2 , presumably in response to minimal clinical and biochemical progress.

With administration of $0.9 \%$ saline, a return to 'normal' blood $\mathrm{Na}^{+}$was achieved 18 hours later (Fig. 1a), which was associated with an accumulated positive fluid balance of 2.9 litres (Fig. 1b). By day 4, the accumulated positive fluid balance was 6.3 litres (Fig. 1b ), in response to which a $20 \mathrm{mg}$ bolus of furosemide was administered every 6 hours. The patient was extubated on day 4 , and urinated copiously on day 5 (Fig. 1a); a documented increase in blood $\mathrm{Na}^{+}$to $146 \mathrm{mmol} / \mathrm{l}$ (hypernatraemia) was documented on day 6 (discharge). An overall accumulated fluid balance of 3.7 litres was noted at discharge. Interestingly, blood CK (day $2=10911 \mathrm{U} / \mathrm{l}$, day $3=35731 \mathrm{U} / \mathrm{l}$, and day $4=36832 \mathrm{U} / \mathrm{l}$ ) continued to increase through day 4 despite normal creatinine and urea concentrations and calculated glomerular filtration rates (eGFR $>90 \mathrm{ml} / \mathrm{min}$ ).

\section{Case 2}

A 25-year-old woman with a past medical history of asthma controlled with salbutamol and recurrent migraines controlled with magnesium salts pulled out of the $109 \mathrm{~km}$ Argus Cycle Tour at $55 \mathrm{~km}$ after $\sim 3$ hours of riding. She trained intermittently but had completed a 21 $\mathrm{km}$ footrace 2 years earlier. Upon waking, she drank $1250 \mathrm{ml}$ of fluid and urinated twice before arriving at the race start, where she drank another $1250 \mathrm{ml}$ of fluid. She continued to drink $1250 \mathrm{ml} / \mathrm{h}$, mostly bottled water with one glass of Coke, until stopping at the $55 \mathrm{~km}$ medical station to rest. She told medical personnel that her arms and legs felt 'tingly' along with a headache, nausea and extreme fatigue. She fell asleep and woke just as the medical crews were preparing to leave. A paramedic agreed to take her home. While being driven, she

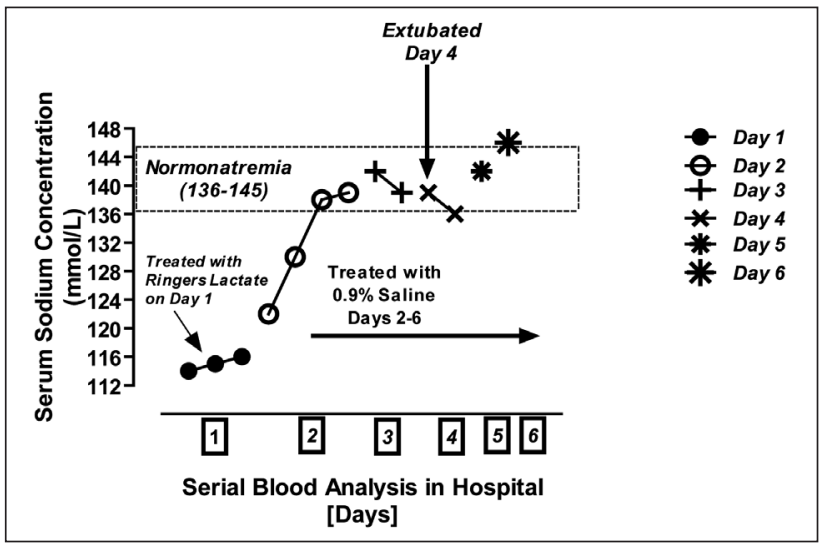

Fig. 1. (a) Serial blood sodium concentration $\left(\mathrm{Na}^{+}\right)$analyses during hospital stay in case 1.

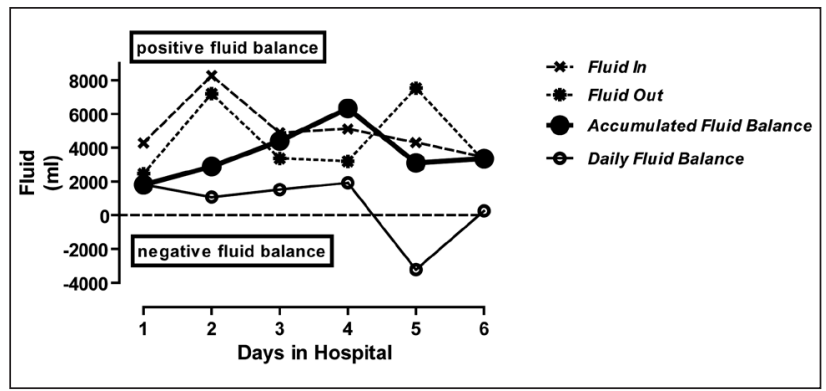

Fig. 1. (b) Fluid balance recorded during hospital stay in case 1. vomited and experienced mental status change, and was immediately taken to the nearest hospital (hospital 1) (Table 1).

On admission she was diagnosed with 'dehydration' despite no blood parameters being measured and was promptly treated with $1600 \mathrm{ml}$ of Ringer's lactate. Her level of consciousness on arrival was $8 / 15$ on the GCS, but it deteriorated and she was transported to a larger hospital (hospital 2) 1 hour later. At hospital 2 she had a subnormal temperature, was combative and vomiting, and was intubated to protect her airway. Blood tests confirmed the diagnosis of hyponatraemia (blood $\mathrm{Na}^{+} 124 \mathrm{mmol} / \mathrm{l}$ ) and a computed tomography scan confirmed cerebral oedema. Intravenous fluid therapy was immediately ceased and she was given a $25 \mathrm{ml}$ bolus of $5 \%$ saline. The $5 \%$ saline was continued at a rate of $75 \mathrm{ml} / \mathrm{h}$ for the first 4 hours and then increased to $100 \mathrm{ml} / \mathrm{h}$ for the next 12 hours or until normonatraemia was achieved (blood $\mathrm{Na}^{+} 135 \mathrm{mmol} / \mathrm{l}$ ). She began to diurese, producing urine at a rate of $300-800 \mathrm{ml} / \mathrm{h}$ for the next 48 hours (urine output data not available). She was extubated 4 days after admission and discharged from hospital on the 5th day with short-term memory loss and difficulties in speech (Table 1). She eventually regained full memory and speech and at the time of writing was training for a $10 \mathrm{~km}$ race with no apparent residual adverse effects.

\section{Discussion}

These two life-threatening cases of EAH with encephalopathy (EAHE) in two signature South African endurance races in 2011 highlight the need to revisit the most appropriate diagnosis and treatment strategies for EAH and EAHE. The EAH Consensus Statement ${ }^{5}$ and Noakes et al. ${ }^{6}$ include the two main risk factors for EAHE: (i) menstruant females moving at a pace slower than the average for most competitors; and (ii) a history of high fluid intake during the race. When coupled with signs and symptoms of vomiting, bloating, weight gain and altered mental status, these factors should immediately suggest a diagnosis of dilutional hyponatraemia in endurance athletes. Medical personnel handling such patients should immediately measure the blood electrolyte concentration whenever faced with such 'classic' EAH presentations as these.

When a diagnosis of dilutional EAHE is confirmed, the most appropriate and life-saving treatment strategy is prompt administration of an intravenous bolus of hypertonic saline. ${ }^{5}$ Such treatment is critical to reduce cerebral oedema and prevent morbidity and mortality associated with brainstem herniation. ${ }^{7}$ The risk of central pontine myelinolysis (CPM) associated with such treatment is low when EAH is treated in this way. EAH is an acute hyponatraemia, and there have been no reported cases of CPM in athletes. A $1-2 \%$ reduction in cerebral oedema associated with administration of a bolus of $100 \mathrm{ml} \mathrm{3 \%}$ hypertonic saline reverses EAHE within a few minutes of treatment. ${ }^{8}$ The increase in blood $\mathrm{Na}^{+}$associated with a $100 \mathrm{ml}$ bolus of $3 \%$ saline is marginal ( $1-2 \%)$, whereas the symptomatic response can be dramatic.

These two cases also illustrate the point that blood sodium concentrations do not always predict the severity of symptoms or response to treatment. Case 1, for example, had a far lower blood $\mathrm{Na}^{+}$level $(112 \mathrm{mmol} / \mathrm{l})$ than case $2(124 \mathrm{mmol} / \mathrm{l})$ on admission. However, case 2's symptoms were more severe and her recovery more prolonged. Current recommendations are to treat the symptoms first in lieu of treating the actual blood sodium value in athletes diagnosed with EAH and EAHE. ${ }^{5}$

In contrast to these current treatment guidelines for EAHE, administration of isotonic fluids such as Ringer's lactate and isotonic saline $(0.9 \%)$ has repeatedly been demonstrated to prolong recovery ${ }^{9,10}$ and result in poorer outcomes. ${ }^{7}$ Both cases 1 and 2 were 
initially treated with Ringer's lactate. In case 1 neither symptoms nor blood $\mathrm{Na}^{+}$improved with such treatment (Fig. 1a), while in case 2 the symptoms worsened appreciably (Table 1), GCS declining from $8 / 15$ to $3 \mathrm{~T} / 15$ ). Table 2 compares the ionic composition of commonly used intravenous fluids in critical care settings and highlights the improved mathematical efficacy of hypertonic versus isotonic saline solutions in raising blood $\mathrm{Na}^{+}$. Isotonic fluid administration is further discouraged in hyponatraemic patients with inappropriate arginine vasopressin secretion. In the syndrome of inappropriate antidiuretic hormone secretion (SIADH), most of the sodium that is administered intravenously is promptly excreted because of the natriuresis that accompanies SIADH. ${ }^{11}$ This concept was hypothetically supported in case 2, in which there was a clear diagnosis of SIADH (as demonstrated with an initial urine $\mathrm{Na}^{+}$level of $189 \mathrm{mmol} / \mathrm{l}$ and urine osmolality of $788 \mathrm{mOsmol} / \mathrm{kg} \mathrm{H} \mathrm{H}_{2} \mathrm{O}$ ) associated with only a modest rise in blood $\mathrm{Na}^{+}(11 \mathrm{mmol} / \mathrm{l})$ with administration of 1.3 litres of $5 \%$ saline (1 $113 \mathrm{mmol} \mathrm{Na}^{+}$total). Unfortunately urine output data were unavailable for case 2, but from a mathematical standpoint (under the assumption of no water or sodium output) the calculated rise in blood $\mathrm{Na}^{+}$from administration of 1.3 litres $5 \%$ saline would have resulted in a substantial (and lethal) blood $\mathrm{Na}^{+}$of $208 \mathrm{mmol} / \mathrm{l}$ in this $58 \mathrm{~kg}$ woman.

Table 1. Timeline of progression for fluid intake, signs and symptoms, and laboratory tests for case 2

\begin{tabular}{|c|c|c|c|c|c|c|}
\hline Timeline & $\begin{array}{l}\text { Pre-race (13 } \\
\text { March) }\end{array}$ & $\begin{array}{l}\text { Cycle race ( } 3 \\
\text { hours' riding) }\end{array}$ & $\begin{array}{l}\text { At } 55 \mathrm{~km} / \\
\text { transport }\end{array}$ & $\begin{array}{l}\text { Hospital } 1 \\
(16: 32,13 \\
\text { March) }\end{array}$ & $\begin{array}{l}\text { Hospital } 2 \\
(17: 30,13 \\
\text { March) }\end{array}$ & $\begin{array}{l}\text { Hospital } 2 \text { (14 - } 18 \\
\text { March) }\end{array}$ \\
\hline Fluid in & $\begin{array}{l}2500 \mathrm{ml} \\
\text { (hypotonic) }\end{array}$ & $\begin{array}{l}3750 \mathrm{ml}(1.25 \mathrm{l} / \mathrm{h} \\
\text { water + Coke) }\end{array}$ & 0 & $\begin{array}{l}1600 \mathrm{ml} \text { Ringer's } \\
\text { lactate (for } \\
\text { diagnosis of } \\
\text { dehydration) }\end{array}$ & $\begin{array}{l}100 \mathrm{ml} \\
5 \% \text { saline } \\
\text { (following } \\
\text { diagnosis of } \\
\text { hyponatraemia) }\end{array}$ & $\begin{array}{l}1200 \mathrm{ml} \\
5 \% \text { saline } \\
(100 \mathrm{ml} / \mathrm{h} \text { for } \\
12 \text { hours until } \\
\text { normonatraemic) }\end{array}$ \\
\hline $\begin{array}{l}\text { Signs } \\
\text { and } \\
\text { symptoms }\end{array}$ & & $\begin{array}{l}\text { Tingling of arms } \\
\text { and legs } \\
\text { Extreme fatigue } \\
\text { and nausea } \\
\text { Headaches }\end{array}$ & $\begin{array}{l}\text { Numbness } \\
\text { (whole body) } \\
\text { Sleepiness } \\
\text { Vomiting } \\
\text { Altered mental } \\
\text { status } \\
\text { Loss of } \\
\text { consciousness } \\
\text { Thoughts of } \\
\text { dying }\end{array}$ & $\begin{array}{l}\text { AMS } \\
\text { Combative and } \\
\text { screaming } \\
\text { GCS } 8 / 15\end{array}$ & $\begin{array}{l}\text { Decorticate } \\
\text { movements } \\
\text { Papilloedema, } \\
\text { bilateral } \\
\text { Unresponsive } \\
\text { plantar reflexes } \\
\text { GCS 3T/15 }\end{array}$ & $\begin{array}{l}14 \text { March } \\
\text { GCS 3T/15 } \\
\text { Papilloedema, } \\
\text { bilateral } \\
\text { Reaction to pain } \\
\text { stimuli } \\
\mathbf{1 7} \text { March } \\
\text { (extubated) } \\
\text { Expressive aphasia } \\
\mathbf{1 8} \text { March } \\
\text { (discharged) } \\
\text { Short-term } \\
\text { memory loss and } \\
\text { monosyllabic } \\
\text { speech }\end{array}$ \\
\hline $\begin{array}{l}\text { Lab tests } \\
\text { and } \\
\text { clinical measures }\end{array}$ & & & & None & $\begin{array}{l}\text { CT scan: cerebral } \\
\text { oedema with } \\
\text { opacified right } \\
\text { maxillary sinus } \\
{\text { Serum } \mathrm{Na}^{+} 124}_{\mathrm{mmol} / 1} \\
\text { Serum } \mathrm{K}^{+} 3.6 \\
\mathrm{mmol} / 1 \\
\text { Serum urea } 2.7 \\
\mathrm{mmol} / 1 \\
\text { Serum creat } 56 \\
\mu \text { mol/1 } \\
\text { WBC } 16.7 \times 10^{\circ} / 1 \\
\text { Urine Na } 189 \\
\mathrm{mmol} / 1 \\
\text { Urine osmolality } \\
788 \mathrm{mOsmol} / 1 \\
\text { Urine specific } \\
\text { gravity } 1.015 \\
\text { Temperature } \\
35.2^{\circ} \mathrm{C} \\
\text { BP } 124 / 89 \mathrm{mmHg} \\
\text { Respiration clear, } \\
14 / \mathrm{min}\end{array}$ & 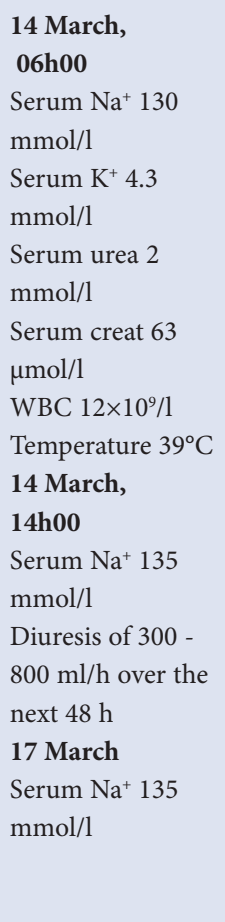 \\
\hline
\end{tabular}


Table 2. Comparison of blood and intravenous fluid composition

\begin{tabular}{|c|c|c|c|c|}
\hline Fluid & $\begin{array}{l}\text { Sodium }\left(\mathrm{Na}^{+}\right) \\
(\mathrm{mmol} / \mathrm{l})\end{array}$ & $\begin{array}{l}\text { Chloride }\left(\mathrm{Cl}^{-}\right) \\
(\mathrm{mmol} / \mathrm{l})\end{array}$ & $\begin{array}{l}\text { Osmolarity } \\
\text { (mOsmol/l) }\end{array}$ & Other \\
\hline Blood (normal range) & $135-145$ & $98-108$ & $280-310$ & \\
\hline Ringer's lactate & 130 & 109 & 273 & $\begin{array}{l}\text { Isotonic } \\
\text { (also contains } \\
28 \mathrm{mmol} / \mathrm{l} \text { lactate, } \\
4 \mathrm{mmol} / \mathrm{l} \text { potassium, } \\
3 \mathrm{mmol} / 1 \text { calcium) }\end{array}$ \\
\hline $0.9 \%$ saline & 154 & 154 & 308 & Isotonic \\
\hline $3 \%$ saline & 513 & 513 & 1027 & Hypertonic \\
\hline $5 \%$ saline & 856 & 856 & 1711 & Hypertonic \\
\hline
\end{tabular}

Of curious physiological interest were the discrepancies between water and sodium balance calculations in association with actual blood $\mathrm{Na}^{+}$changes, particularly with regard to case 1 , for whom we were able to obtain detailed input and output data from hospital records. These revealed a progressively positive fluid balance associated with the recovery of blood $\mathrm{Na}^{+}$(Fig. 1b). This was curious because we would have expected that a positive fluid balance, commonly associated with dilutional hyponatraemia, would have normalised during recovery with an associated diuresisinduced negative fluid balance, similar to that seen on day 5 (Fig. 1b). This overall positive fluid balance during recovery was unexpected. This suggests that these discrepancies in actual versus measured changes in blood sodium concentration highlight the complexity of fluid and sodium homeostasis, possibly related to osmotic activation and inactivation of sodium stores under nonsteady-state conditions. ${ }^{6}$ Also unknown were the non-osmotic stimuli to arginine vasopressin secretion, which facilitated fluid retention in these two athletes. Potential non-osmotic stimuli resulting in arginine vasopressin secretion include event stress, heat, plasma volume contraction, ciprofloxacin use (case 1) or many unknown exercise-related stimuli.

In conclusion, female athletes moving relatively slowly and with a history of high fluid intake who present to medical personnel with vomiting and mental status changes should be evaluated promptly for EAH. If symptomatic hyponatraemia is confirmed via a blood test, the recommended treatment is administration of an intravenous dose of hypertonic saline (100 $\mathrm{ml} \mathrm{3 \%}$ or $50 \mathrm{ml} 5 \%$ saline) to reverse cerebral oedema. Administering Ringer's lactate to symptomatic athletes without a blood test to rule out or confirm a diagnosis of hyponatraemia should be discouraged, as it can result in a fatal outcome. $^{12}$

Disclosure. The authors have no conflict or competing interests to disclose.

\section{References}

1. Noakes TD, Goodwin N, Rayner BL, Branken T, Taylor RK. Water intoxication: a possible complication during endurance exercise. Med Sci Sports Exerc 1985;17(3):370-375.

2. Hew-Butler T, Sharwood K, Boulter J, et al. Dysnatremia predicts a delayed recovery in collapsed 2. Hew-Butler T, Sharwood K, Boulter J, et al. Dysnatremia
ultramarathon runners. Clin J Sport Med 2007;17:289-296.

ultramarathon runners. Clin J Sport Med 2007;17:289-296.
3. Sharwood K, Collins M, Goedecke J, Wilson G, Noakes T. Weight changes, sodium levels, and 3. Sharwood K, Collins M, Goedecke J, Wilson G, Noakes T. Weight changes, sodium lever
performance in the South African Ironman Triathlon. Clin J Sport Med 2002;12(6):391-399.

4. Sharwood K, Collins M, Goedecke J, Wilson G, Noakes T. Weight changes, medical complications and performance during an Ironman triathlon. Br J Sports Med 2004;38(6):718-724

5. Hew-Butler TD, Ayus JC, Kipps C, et al. Statement of the Second International Exercise-Associated Hyponatremia Consensus Development Conference, New Zealand, 2007. Clin J Sport Med 2008;18(2):111-121.

6. Noakes TD, Sharwood K, Speedy D, et al. Three independent biological mechanisms cause exerciseassociated hyponatremia: evidence from 2,135 weighed competitive athletic performances. Proc Natl Acad Sci USA 2005;102(51):18550-18555.

7. Ayus JC, Varon J, Arieff AI. Hyponatremia, cerebral edema, and noncardiogenic pulmonary edema in marathon runners. Ann Intern Med 2000;132(9):711-714.

8. Siegel AJ, Verbalis JG, Clement $\mathrm{S}$, et al. Hyponatremia in marathon runners due to inappropriate

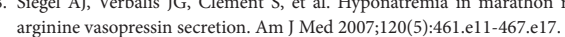

9. Hew-Butler T, Noakes TD, Siegel AJ. Practical management of exercise-associated hyponatremic Hew-Butler T, Noakes TD, Siegel AJ. Practical management of exercise-associated hyponatremic
encephalopathy: The sodium paradox of non-osmotic vasopressin secretion. Clin J Sport Med encephalopathy: The sodium paradox of non-osmotic vasopressin secretion. Clin J Sport Med 2008; 18(4):350-35

10. Davis DP, Videen JS, Marino A, et al. Exercise-associated hyponatremia in marathon runners: a twoyear experience. J Emerg Med 2001;21(1):47-57.

11. Schwartz WB, Bennett W, Curelop S, Bartter FC. A syndrome of renal sodium loss and hyponatremia probably resulting from inappropriate secretion of antidiuretic hormone. 1957. J Am Soc Nephrol 2001;12(12):2860-2870. [http://dx.doi.org/10.1016/0002-9343(57)90224-3]

12. Thompson JA, Wolff AJ. Hyponatremic encephalopathy in a marathon runner. Chest 2003;124(4):313S.

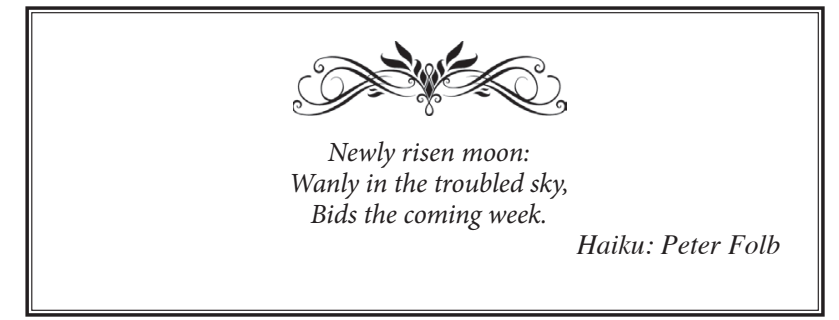

